\title{
AVANÇOS E POLÊMICAS: A RATIFICAÇÃO DA CONVENÇÃO DE NOVA IORQUE E A QUESTÃo DA NECESSIDADE DE HOMOLOGAÇÃO DE SENTENÇAS ARBITRAIS ESTRANGEIRAS.
}

\author{
Dayana de Carvalho Uhdre ${ }^{1}$
}

\section{RESUMO}

Haveria ainda, com a ratificação da Convenção de Nova York, a necessidade de homologação de sentenças arbitrais estrangeiras pelo STJ? A polêmica centra-se na interpretação do artigo $3^{\circ}$ da Convenção: parte da doutrina defende a desnecessidade do exequatur; já a outra, majoritária, argüi da necessidade do procedimento.Trazendo a lume os argumentos de ambas as correntes, objetiva-se, por meio desse paralelo, aclarar, (e, porque não acalorar?) a discussão. Para tanto, utiliza-se, além de consultas doutrinárias, consultas jurisprudenciais, de legislação pátria, bem como de legislação comparada.

\section{ABSTRACT}

The present work has for object to argue if still has, with the ratification of the Convention of New York, the necessity of homologation of foreign arbitral awards for the STJ. The controversy centered in the interpretation of the article $3^{\circ}$ of the Convention: one part of the doctrine defended the unecessity of exequatur; while other, a major one, argued of the necessity of the procedure. So, first at all, will be showed the arguments of the both thoughts. After this, we will be able to discute, and adote one (or none) of those doctrine. Beyond doctrinal consultations, were used cases laws consultations, local (brasilian) legislation, as well as comparative legislation.

\footnotetext{
${ }^{1}$ Acadêmica de Direito da Universidade Federal do Paraná e Integrante do Núcleo de Estudos em Direito Internacional da Universidade Federal do Paraná
}

Revista Brasileira de Direito Internacional, Curitiba, v.2, n.2, jul./dez.2005 
PALAVRAS CHAVES: HOMOLOGAÇÃO - SENTENÇAS ARBITRAIS CONVENÇÃO DE NOVA IORQUE.

KEYWORDS: HOMOLOGATION - ARBITRAL AWARDS - NEW YORK
CONVENTION.

\title{
1 INTRODUÇÃO
}

\begin{abstract}
"The entry into force of the NY and Panama Conventions has meant the modernization of local arbitration laws eliminating the traditional nonrecognition of the arbitration clause as a valid submission to arbitration". ${ }^{2}$
\end{abstract}

Antes de mais nada, mister é se enfocar o grande salto dado pelo sistema pátrio ao se adotar as Convenções Internacionais, notadamente a de Nova lorque e a do Panamá, tratantes da Arbitragem.

Destarte, a adoção, e mais ainda o aprimoramento, do instituto da arbitragem é de interesse econômico, empresarial, social, sindical e até mesmo do Poder Judiciário.

Ora, o fenômeno da Hipermodernidade, pontuado pelo filósofo francês Gilles Lipovetsky ${ }^{3}$, acaba por imprimir, à atual sociedade, o excesso, o hiper: de negócios, de riquezas econômicas, de litígios judiciais, etc (fala-se então em hipercapitalistas, hipericos, mega-empresários). Sendo assim, as estruturas ditas modernas de resolução de litígios, v.g, não mais respondem a estas "hiperdemandas"; necessário, pois, a adoção de outros métodos mais condizentes a esta nova realidade.

Neste espectro, a dinamicidade, a celeridade, a informalidade, princípios sempre inerentes ao desempenho da atividade comercial, ganham uma dimensão exagerada, uma dimensão global, internacional, de maneira que os institutos tradicionais/modernos perdem em eficácia. E, é nesse contexto que entra $o$ instituto da arbitragem, que veio a reforçar os princípios acima elencados e tão vitais à manutenção e ao desenvolvimento do comércio hodierno, de escala internacional.

\footnotetext{
${ }^{2}$ CREMADES, Bernardo M. Latin American Courts and International Arbitration. In.: Revista de Arbitragem e Mediação, n.. 3, p.29.

3 VANNUCHI, Camilo. A Sociedade do Excesso. In: Revista ISTO É. Extraído do site www.terra.com.br/istoe/1819/comportamento/1891 sociedade do excesso.htm, acessado em 02/09/2005.
}

Revista Brasileira de Direito Internacional, Curitiba, v.2, n.2, jul./dez.2005 
Tradicionalmente, a América Latina, inclusive o Brasil, via a arbitragem como interferência ou derrogação da autoridade do Judiciário; concepção essa tolhedora do desenvolvimento da arbitragem. Realmente, dentre os obstáculos impostos à arbitragem, os mais importantes seriam: (a) o não reconhecimento da executividade da arbitragem, sem a confirmação de sua previsão (cláusula arbitral) por meio do compromisso arbitral; e (b) o duplo exequatur. ${ }^{4}$

No âmbito brasileiro, as dificuldades se avolumavam: na arbitragem nacional era preciso, além de se firmar o compromisso arbitral, a homologação do laudo arbitral proferido; já na internacional, era necessária, como dito supra, a dupla homologação (pelo STF, e por corte judiciária situada na localidade da arbitragem). ${ }^{5}$

A partir da década de 80 , contudo, tal cenário, paulatinamente modificou-se, forçado, dentre outros motivos, pela crescente necessidade de inserção destas nações ao comércio internacional. De fato, as ratificações, graduais, da Convenção Interamericana sobre Arbitragem Comercial Internacional, firmada em 1975 no Panamá, e da Convenção sobre Reconhecimento e Execução de Sentenças Arbitrais Estrangeiras (Convenção de Nova lorque) de 1958, por quase a totalidade dos países latino-americanos demonstram, em linhas gerais, a adequação destes ao cenário mundial de comércio, cada vez mais caracterizado pelo princípio da autonomia da vontade. Na verdade, poder-se-ia afirmar ser o reconhecimento deste princípio resultado direto da ratificação destas Convenções. ${ }^{6}$

No Brasil, o instituto da arbitragem, teve ademais, sua importância reconhecida com a edição da Lei de Arbitragem, Lei 9.307/1996. Realmente, a doutrina pátria mais abalizada ressalta o reconhecimento do princípio da autonomia da vontade quando da edição desta lei - verificável da leitura dos primeiros artigos da Lei 9.307/96. Contudo, foi com a promulgação da Convenção de Nova lorque (através do Decreto Executivo 4.311, de

\footnotetext{
${ }^{4}$ CREMADES, Bernardo M. Latin American Courts and International Arbitration. In.: Revista de Arbitragem e Mediação, n. 3, p.20.

${ }^{5}$ AMARAL, Antônio Carlos Rodrigues do (coord.). Direito do Comércio Internacional: Aspectos Fundamentais, p. 334.

${ }^{6}$ CREMADES, Bernardo Latin American Courts and International Arbitration. In.: Revista de Arbitragem e Mediação, n.ำ 3, p.29.
}

Revista Brasileira de Direito Internacional, Curitiba, v.2, n.2, jul./dez.2005 
23/07/2002), que o Brasil adequou-se, mais efetivamente, às modernas regras do direito comercial internacional, "além de representar uma importante contribuição para a melhor inserção das empresas brasileiras no cenário mundial". 7

Neste contexto, e visando a uma compreensão mais acertada da importância e do avanço tido com a ratificação da Convenção de Nova lorque, imprescindível se examinarem os eventuais efeitos (sinônimos ou não de avanços) desta internalização. Dentre estes, limitar-se-á à análise da polêmica suscitada quanto à necessidade, ou não, de homologação das sentenças arbitrais estrangeiras, trazendo a lume os argumentos de ambas as correntes, para que se possa, então, tomar partido em uma ou outra direção. Para tanto, utilizar-se-á, além de consultas doutrinárias, consultas jurisprudenciais, de legislação pátria, bem como de legislação comparada.

\subsection{EFEITOS DA INTERNALIZAÇÃO DA CONVENÇÃO DE NOVA} IORQUE

Visando a uma melhor análise dos eventuais efeitos da adoção, pelo sistema pátrio, da Convenção, imprescindível subdividir o presente item em dois sub-tópicos: reflexos na eficácia internacional de sentenças arbitrais estrangeiras; e reflexos em nosso regime homologatório. Perceba-se, porém, desde já, que é neste último campo que reside a divergência objeto do presente estudo (necessidade ou não do exequatur).

1.1.1Reflexos na Eficácia Internacional de Sentenças Arbitrais Estrangeiras

É neste âmbito que possíveis avanços no instituto da arbitragem serão atingidos. De fato, muitos dos países signatários da Convenção de Nova lorque

\footnotetext{
${ }^{7}$ VERÇOSA, Fabiane. A (Des?) Necessidade de Homologação de Laudos Arbitrais Estrangeiros após a Entrada em Vigor, no Brasil, da Convenção de Nova lorque.In: Revista de Direito Mercantil, n.ำ131, p.214.
}

Revista Brasileira de Direito Internacional, Curitiba, v.2, n.2, jul./dez.2005 
fizeram uso da reserva de reciprocidade, prevista em seu art. I, $\S 3^{\circ}{ }^{8}$, sendo que a maioria deles não aderiram à Convenção do Panamá de $1975^{9}$. Dessa forma, uma sentença arbitral proferida no Brasil poderia não ser reconhecida em outro Estado, v.g., a Inglaterra, em virtude exatamente da adesão deste, com a ressalva de reciprocidade, na Convenção de 1958; e da não internalização deste mesmo Tratado pelo nosso país.

Ademais, em muitos casos é a parte brasileira, vencedora em uma arbitragem internacional, realizada em território nacional, a única interessada em invocar num país estrangeiro os efeitos inerentes à sentença arbitral brasileira; uma vez que, provavelmente será neste Estado estrangeiro que estarão os ativos pertencentes à outra parte (alienígena) condenada.

Em outras palavras, ao ratificar-se a "Convenção de Nova lorque de 1958, estamos contribuindo para o incremento da eficácia internacional de sentenças arbitrais proferidas no Brasil, e indiretamente, garantindo maior segurança às partes brasileiras eventualmente vencedoras em uma instância arbitral" ${ }^{\prime 10}$.

Dito isso, conclui-se que a ratificação da Convenção de Nova lorque de 1958 representa significativo incremento na eficácia internacional de sentenças arbitrais brasileiras, o que, sem dúvida, contribui para a promoção de nosso país à praça internacional de arbitragem e assegura aos operadores comerciais brasileiros um regime jurídico mais favorável quando necessário executar bens, localizados em estados estrangeiros, da parte alienígena condenada.

\footnotetext{
${ }^{8}$ Ex vi: "Artigo I

(...)

3. Quando da assinatura, ratificação ou adesão à presente Convenção, ou da notificação de extensão nos termos do art. X, qualquer Estado poderá, com base em reciprocidade, declarar que aplicará a Convenção ao reconhecimento e à execução de sentenças proferidas unicamente no território de outro Estado signatário. Poderá igualmente declarar que aplicará a Convenção somente a divergências oriundas de relacionamentos jurídicos, sejam eles contratuais ou não, que sejam considerados como comerciais nos termos da lei nacional do Estado que fizer tal declaração"(grifamos).

${ }^{9}$ De fato, esta Convenção está mais adstrita aos países americanos; de modo que as nações européias não a aderiram. Outrossim, a aludida Convenção não exige reciprocidade.

${ }_{10}$ VALENÇA FILHO, Clávio de Melo. Ratificação da Convenção sobre o Reconhecimento e Execução de Sentenças Arbitrais Estrangeiras (Nova lorque, 1958). In: Revista de Direito Bancário, do Mercado de Capitais e da Arbitragem, n.ำ16, p. 389.
}

Revista Brasileira de Direito Internacional, Curitiba, v.2, n.2, jul./dez.2005 


\subsubsection{Reflexos em Nosso Sistema Homologatório}

Anteriormente à adoção da Convenção de Nova lorque, o nosso sistema homologatório era regulado por duas fontes principais: a Lei Marcos Maciel (Lei de Arbitragem) e a Convenção Interamericana sobre Arbitragem Comercial Internacional (Panamá de 1975). Desta forma, analisaremos os efeitos em relação à estas duas fontes.

Contudo, imperioso salientar, desde agora, que, por força no disposto no art. 34 da Lei 9.307/96, esta última fonte (chamada de fonte interna) era inferior hierarquicamente sobre a denominada fonte convencional; de modo que, seria a Convenção do Panamá o principal diploma regulador da homologação de Arbitragem estrangeira. Dito de outro modo, o regime homologatório da Convenção do Panamá de 1975 constitui o direito comum em matéria de homologação de sentenças arbitrais estrangeiras proferidas em matéria comercial internacional.

Pois bem. Em relação à fonte convencional, a internalização da Convenção de Nova lorque não lograria vantagens ou desvantagens à eficácia de sentenças arbitrais estrangeiras; porquanto, o regime estabelecido na Convenção do Panamá tem por base a Convenção de Nova lorque. Destarte, "as condições de homologação impostas pelo art. V da Convenção do Panamá do (sic) 1975 são idênticas àquelas contidas no art. V da Convenção de Nova lorque, isso por um simples motivo: acatou-se, durante os trabalhos de elaboração da Convenção do Panamá, proposta do delegado equatoriano no sentido de transplantar-se à Convenção do Panamá de 1975 o art. V da Convenção de Nova lorque de 1958"11.

Já em relação à fonte interna, e de acordo com a maioria da doutrina, também não teríamos grandes inovações; uma vez que, da "análise de todas as normas da Lei 9.307/1996, de 23.09.1996, referentes ao reconhecimento e à execução de sentenças arbitrais estrangeiras, revela $(-$ se),(...), uma influência

${ }^{11}$ VALENÇA FILHO, Clávio de Melo. Op.cit., p. 388.

Revista Brasileira de Direito Internacional, Curitiba, v.2, n.2, jul./dez.2005 
muito forte da Convenção de Nova lorque, de 10.6.1958"12. Todavia, uma minoria doutrinária defende que a internalização da Convenção de Nova lorque acarretaria grande alteração no sistema homologatório vigente; uma vez que deixaria de ser aplicável a norma da Lei de Arbitragem que requer a prévia homologação da sentença arbitral estrangeira (o exequatur do STJ). ${ }^{13}$

Posto isso, centramo-nos, doravante, no objeto do presente trabalho; a saber, a persistência ou não, com a internalização da Convenção de Nova lorque, da necessidade de homologação das sentenças arbitrais estrangeiras. Para tanto, passaremos a analisar os argumentos a favor e os contra a obrigatoriedade do exequatur.

\section{DA DESNECESSIDADE DE HOMOLOGAÇÃO}

Os autores que defendem uma mudança significativa, com a adesão do Brasil à Convenção de Nova lorque, em nosso sistema homologatório de sentenças arbitrais estrangeiras (regulado pela Lei 9.307/1996), pautam-se nos argumentos abaixo categorizados.

\subsection{DA CONFUSÃO SEMÂNTICA: ARBITRAGEM ESTRANGEIRA OU INTERNACIONAL?}

A Lei 9.307/1996 dispõe, em seu art. 34, que configura laudo arbitral estrangeiro o laudo produzido fora do território nacional; ou seja, é o local onde proferido o laudo que the caracteriza a nacionalidade. Agindo dessa forma, a lei deixou de distinguir arbitragem estrangeira da internacional; distinção essa importante, tendo-se em conta que a ordem pública nacional e internacional regem-se por princípios, por vezes, destoantes.

É certo que nem sempre é fácil diferenciá-las. Contudo, pode-se dizer que a arbitragem estrangeira resolve um "litígio subordinado inteiramente a

\footnotetext{
${ }^{12}$ RECHSTEINER, Beat Walter. Arbitragem Privada Internacional: Teoria e Prática, $2^{\underline{a}}$ ed., p.143.

13 Observe-se que anteriormente à EC 45/2004, a competência para proferir o exequatur era do STF.
}

Revista Brasileira de Direito Internacional, Curitiba, v.2, n.2, jul./dez.2005 
uma ordem jurídica nacional determinada, em que todos os elementos da relação jurídica controvertida estão sujeitos a essa ordem jurídica". Assim, v.g., um contrato regido pela lei inglesa, que tem por objeto bem situado na Inglaterra e por partes pessoas domiciliadas nesse mesmo Estado, é um contrato nacional, e a arbitragem que dirimir controvérsias dele oriundas será nacional; porém, estrangeiro para os outros países. A arbitragem internacional seria aquela que "soluciona controvérsias de caráter internacional, sejam porque as partes possuam domicílio em diferentes países, seja porque o objeto do contrato se situe em outra ordem jurídica, (...). Em outras palavras, a relação jurídica controvertida envolve mais de uma ordem jurídica nacional, embora possa ser regida por uma lei nacional”14.

Observe-se que, de fato, a arbitragem estrangeira e a internacional, relacionam-se com ordens públicas de caracteres diferentes. Ora, arbitragem estrangeira, só a é se tomamos por ponto de referência país distinto do Estado em que a "sentença" fora proferida. Do mesmo modo, será laudo nacional, se a referência for agora o Estado em que o mesmo fora pronunciado. Disto concluise que, a arbitragem estrangeira/nacional é aquela inerente a dirimir controvérsias de contratos nacionais, ou seja, estaria relacionado à questão de ordem pública nacional. Já a arbitragem internacional, exatamente por ter sobre ele a incidência de duas ordens jurídicas distintas, destina-se a dirimir litígios decorrentes do comércio internacional; de forma que deverá, tal arbitragem, estar subordinada à ordem pública internacional.

Sabemos, porém, que em face da flexibilidade, da dinamicidade, da informalidade intrínsecas ao comércio internacional, na ordem pública internacional, o princípio da autonomia da vontade ganha um ambiente muito mais propício. Sendo assim, justificada está a atribuição de maiores formalidades à conformação das sentenças arbitrais estrangeiras/internas. É nesse sentido, conforme assevera José Carlos de Magalhães, que a França estabeleceu critérios diversos para reger a arbitragem interna e a internacional; seguindo, assim, a orientação adotada pela Convenção Européia sobre Arbitragem Internacional, firmada em Genebra em 1961.

\footnotetext{
14 MAGALHÃES, José Carlos de. Reconhecimento e Execução de Laudos Arbitrais Estrangeiros.In.: RT n. 9 740, p. 120.
}

Revista Brasileira de Direito Internacional, Curitiba, v.2, n.2, jul./dez.2005 
Todavia a legislação brasileira, como já fora dito, ignorou tal distinção, preferindo se ater à noção de arbitragem estrangeira aquela proferida fora do território nacional; de forma que, condicionamos o reconhecimento e execução do laudo à observância da lei estrangeira, mesmo que nenhum efeito venha a ter, a decisão, no local aonde fora proferida (art. 38, VI da Lei de Arbitragem). Residiria, aqui, pois, um retrocesso no tocante ao instituto da arbitragem: ora, se o laudo não contrariar a ordem pública internacional ou a ordem pública brasileira, não haveria de se impedir sua execução no Brasil, ainda que contrarie a lei do país onde foi proferido.

Tal entendimento, perceba-se, corrobora a noção de laudo arbitral enquanto constituído de natureza privada (objeto de nosso próximo subitem).

\title{
2.2 SENTENÇA JUDICIAL ESTRANGEIRA E LAUDO ARBITRAL PROFERIDO NO EXTERIOR: A NATUREZA PRIVADA DA "SENTENÇA ARBITRAL"
}

A jurisdição do árbitro provém das partes, tem, pois, natureza privada. O contrário ocorre com a jurisdição do juiz, que por advir da Constituição, e das leis regulatórias da mesma (em uma palavra da comunidade nacional) tem natureza pública. E, é neste sentido a lição de José de Magalhães:

\begin{abstract}
"Se o laudo arbitral é ato privado decorrente da vontade das partes, destinado a dirimir controvérsia sobre relação contratual de natureza patrimonial - e, portanto, de caráter disponível - não há intervenção de autoridade pública estrangeira que justifique sua prévia aceitação pelo órgão judiciário brasileiro. Os contratos celebrados no exterior e exeqüíveis no Brasil não necessitam ser apresentados a qualquer Poder Público do país, para serem reconhecidos ou para que sua execução ou cumprimento pela parte aqui domiciliada seja autorizado. (...). E, não há diferença da natureza privada entre um contrato privado celebrado no exterior e um laudo arbitral, elaborado também no exterior, por árbitro que resolva uma controvérsia sobre esse mesmo contrato. Tanto o laudo como o contrato são instrumentos que decorrem de uma relação privada que tem por objeto um direito de caráter patrimonial privado e, assim, disponível." 15
\end{abstract}

Ora, a homologação de sentenças judiciais estrangeiras, sob esse prisma, se justifica por serem estas, atos de autoridade pública de outro

${ }^{15}$ MAGALHÃES, José Carlos de. Op. cit, p. 118.

Revista Brasileira de Direito Internacional, Curitiba, v.2, n.2, jul./dez.2005 
Estado; de modo que, o país aonde deve ser cumprido a sentença pode ou não admitir, dependendo de convenções internacionais de reciprocidade, ou da lei. É exatamente nesse sentido que a nossa Constituição assevera, em seu art. 181: "O atendimento de requisição de documentos ou informações de natureza comercial, feita por autoridade administrativa ou judiciária estrangeira, a pessoa física ou jurídica residente ou domiciliada no País dependerá de autorização do Poder competente". Em outras palavras, trata-se de defesa da soberania estatal: um Estado, devido à soberania que lhe é inerente, pode ou não aceitar e executar ato de autoridade pública judiciária de outro país. Trata-se, em poucas palavras, de relacionamento entre Estados soberanos.

Não é esse o caso do laudo arbitral. De fato, como já fora dito, por ser ato de natureza privada, destituído, portanto, de poder público, não há o porquê da exigência de prévia homologação por Corte Judiciária. Neste espectro, José de Magalhães pontua que, não obstante a Lei 9.307/96, equivocadamente, subordinar o reconhecimento e execução do laudo arbitral produzido no exterior à prévia homologação pelo STF (agora pelo STJ), a competência constitucional daquela Corte se refere à homologação de sentenças judiciais estrangeiras.

\subsection{DA COMPETÊNCIA CONSTITUCIONAL DO STJ}

Uma vez posto que dentre as competências constitucionais do STJ está a homologação de sentenças judiciais estrangeiras, salta a questão da possibilidade de se ampliar por lei ordinária o rol de competências desta Corte.

A competência originária do STJ, como se sabe, está prevista no art. 105, da Constituição Federal, ex vi:

\footnotetext{
“Art. 105. Compete ao Superior Tribunal de Justiça:

I - processar e julgar, originariamente:

a) nos crimes comuns, os Governadores dos Estados e do Distrito Federal, e, nestes e nos de responsabilidade, os desembargadores dos Tribunais de Justiça dos Estados e do Distrito Federal, os membros dos Tribunais de Contas dos Estados e do Distrito Federal, os dos Tribunais Regionais Federais, dos Tribunais Regionais Eleitorais e do Trabalho, os membros dos Conselhos ou Tribunais de Contas dos Municípios e os do Ministério Público da União que oficiem perante tribunais;
}

Revista Brasileira de Direito Internacional, Curitiba, v.2, n.2, jul./dez.2005 
b) os mandados de segurança e os habeas data contra ato de Ministro de Estado, dos Comandantes da Marinha, do Exército e da Aeronáutica ou do próprio Tribunal (Redação dada pela Emenda Constitucional n 23, de 1999) c) os habeas corpus, quando o coator ou paciente for qualquer das pessoas mencionadas na alínea "a", ou quando o coator for tribunal sujeito à sua jurisdição, Ministro de Estado ou Comandante da Marinha, do Exército ou da Aeronáutica, ressalvada a competência da Justiça Eleitoral; (Redação dada pela Emenda Constitucional no 23, de 1999)

d) os conflitos de competência entre quaisquer tribunais, ressalvado o disposto no art. 102, I, "o", bem como entre tribunal e juízes a ele não vinculados e entre juízes vinculados a tribunais diversos;

e) as revisões criminais e as ações rescisórias de seus julgados;

f) a reclamação para a preservação de sua competência e garantia da autoridade de suas decisões;

g) os conflitos de atribuições entre autoridades administrativas e judiciárias da União, ou entre autoridades judiciárias de um Estado e administrativas de outro ou do Distrito Federal, ou entre as deste e da União;

h) o mandado de injunção, quando a elaboração da norma regulamentadora for atribuição de órgão, entidade ou autoridade federal, da administração direta ou indireta, excetuados os casos de competência do Supremo Tribunal Federal e dos órgãos da Justiça Militar, da Justiça Eleitoral, da Justiça do Trabalho e da Justiça Federal;

i) a homologação de sentenças estrangeiras e a concessão de exequatur às cartas rogatórias;(Incluída pela Emenda Constitucional n 45, de 2004)"

Contudo, parece que 0 art. $35^{16}$ da Lei de Arbitragem também prevê outra hipótese, hipótese essa não arrolada no corpo constitucional. Ora, como é notório, estando a competência do STJ fixada na Constituição, parece evidente que qualquer modificação, supressão ou ampliação dessa competência implica em alterar o dispositivo constitucional, equivalendo, portanto, a uma emenda à Constituição, o que exige tramitação especial (art.60 da Carta Magna).

Outrossim, o fato de a Constituição deixar claro que em determinados casos a competência será fixada por lei (caso do Tribunal Superior do Trabalho, v.g), deixando de prever norma similar para o Superior Tribunal de Justiça $^{17}$, revela que o constituinte quis estabelecer competência fixa e determinada para essa Corte, somente modificável via emenda constitucional.

Cabe, por fim, destacar outro argumento arrolado pelos defensores da desnecessidade de homologação por parte do STJ, a saber o alcance da norma constitucional. Enfocam, esses doutrinadores, que o que a Constituição

\footnotetext{
${ }^{16}$ Ex vi: "Art. 35. Para ser reconhecida ou executada no Brasil, a sentença arbitral estrangeira está sujeita, unicamente, à homologação do Supremo Tribunal Federal". Com a Emenda Constitucional n.․ 45/2005, como já fora dito, a competência passou a ser do STJ.

${ }_{17}$ Deixa de prever norma similar também para o Supremo Tribunal Federal, para os Tribunais Regionais Federias e para os Juízes Federais.
}

Revista Brasileira de Direito Internacional, Curitiba, v.2, n.2, jul./dez.2005 
dispõe em seu art. 105, I, i, é ser de competência originária do STJ "a homologação das sentenças estrangeiras (...)"; entenda-se a mesma como sentença judicial estrangeira, provinda de Estado estrangeiro, portanto dotada de caráter oficial.

Em suma, por não ser o laudo arbitral (não obstante a nomenclatura utilizada pela Lei n. 9.307/96) sentença estrangeira, não é da competência constitucional do STJ sua homologação. Ademais, e exatamente por ser de hierarquia constitucional o estabelecimento da competência dessa Corte Judiciária, é defeso a lei ordinária modificar a distribuição dessas prerrogativas. Sendo assim, o disposto no art. 35 da Lei de Arbitragem é inconstitucional.

\subsection{O ARTIGO 3 DA CONVENÇÃO DE NOVA IORQUE}

Até agora, trataram-se de argumentos reforçadores da tese da desnecessidade de homologação de sentenças arbitrais estrangeiras, não se analisando, especificamente, a Convenção de Nova lorque. Dessa forma, mister é a centralização do debate na análise desse Acordo de 1958. É o que se passa a fazer.

Argúem os defensores da desnecessidade de homologação que com a internalização do Tratado de 1958, a defesa da homologação se tornaria insustentável; vez que, contrário ao ordenamento pátrio. A contrariedade, frisese, encontrar-se-ia na letra dessa Convenção, mais detalhadamente em seu art. 3ํ. Convém, para uma análise mais reta, transcrevermos o artigo referido:

\footnotetext{
“Artigo III

Cada Estado signatário reconhecerá as sentenças como obrigatórias e as executará em conformidade com as regras de procedimento do território no qual a sentença é invocada, se acordo com as condições estabelecidas nos artigos que se seguem. Para fins de reconhecimento ou de execução das sentenças arbitrais às quais a presente Convenção se aplica, não serão impostas condições substancialmente mais onerosas ou taxas ou cobranças mais altas do que as impostas para o reconhecimento ou para a execução de sentenças arbitrais domésticas".
}

Revista Brasileira de Direito Internacional, Curitiba, v.2, n.2, jul./dez.2005 
Pois bem. Uma vez que entre em vigor um Tratado Internacional, o mesmo vigerá, posteriormente a sua publicação (mais especificamente 45 dias após a publicação, art.1ํ da LICC), com força de lei ordinária.

Da simples leitura do enxerto (da Convenção) acima, percebe-se que esse Tratado é claro quanto à vedação, para fins de reconhecimento ou execução de sentenças arbitrais estrangeiras, de eventuais imposições mais onerosas, comparativamente ao reconhecimento e execução de sentenças arbitrais domésticas.

A execução de sentenças arbitrais doméstica, no Brasil, com o advento da Lei Marcos Maciel, prescinde da "homologação judicial", constituindo, essa sentença, por força do disposto em nosso diploma processual (art. 584, II, do (PC), título executivo judicial. Contrariamente, essa mesma lei estabelece a necessidade de homologar-se as sentenças arbitrais alienígenas.

Sendo assim, de uma análise apriorística - contudo, de clareza incontestável - concluir-se-ia que o procedimento homologatório estaria abrangido pela expressão "condições substancialmente mais onerosas"; de modo que, constituiria um óbice, uma dificuldade a mais, dificuldade essa imposta apenas a sentenças arbitrais estrangeiras.

Ora, estar-se-ia diante de um conflito normativo: de um lado, a Lei de Arbitragem prevendo a necessidade de homologação; de outro, a Convenção (que, uma vez internalizada, adquire status de lei) determinando a equivalência na execução de sentenças arbitrais domésticas e alienígenas.

Pois bem. Tendo-se em conta que o nosso ordenamento é um sistema, e como tal caracteriza-se pela coerência, unicidade e ordem, inadmissível a presença de antinomias legais. Assim, diante da presença desse "fenômeno desagregador", caberá ao intérprete resolver esse conflito, utilizando, para tanto, as ferramentas postas pelo próprio ordenamento. Sistematiza a doutrina três "regras" para a resolução desses conflitos: "lei superior revoga anterior"; "lei posterior revoga anterior"; "lei especial revoga lei geral". Importante, nessa questão, ressaltar que o que se revoga é o disposto em contrário (a parte que Ihes sejam antinômicas). Ademais, a solução das antinomias obedece exatamente a ordem acima exposta. 
Posto isto, o caso sub exame põe em relevo o conflito entre duas normas de mesma hierarquia; de maneira que, o primeiro postulado não cabe na resolução dessa antinomia. Continuando, pois, esse percurso, depara-se com normas cronologicamente distintas: a Lei de Arbitragem teve sua publicação em 1996, ao passo que a Convenção de Nova lorque iniciou sua vigência (no âmbito brasileiro) em 2002. Logo, por força no contido no art. $2^{\circ}$, $\S$ $1^{\circ}$ da LICC, lei posterior derroga anterior, quando com ela incompatível. Observe-se, porém, e enfatizando o que fora dito antanho, que não se revoga toda a Lei de Arbitragem, mas apenas naquilo em que sejam reciprocamente antagônicas. Dessa forma, aplicável seria o disposto no Tratado de Nova lorque, o qual proíbe imposição de condições mais onerosas a execução de sentenças estrangeiras do que aquelas estabelecidas para as sentenças domésticas.

Em suma, com o advento, mais especificamente com a internalização, da Convenção de Nova lorque de 1958, a necessidade de homologar-se as sentenças arbitrais alienígenas estaria revogada: a uma porque o que a Carta Magna prevê é a necessidade do exequatur para sentenças judiciais estrangeiras; a duas porque ante a antinomia entre os dispostos na Lei Marcos Maciel e no Tratado nova iorquino, prevaleceria, pelo critério cronológico, o estabelecido nesse último (a saber, a vedação a exigências díspares para execução de laudos arbitrais domésticos e alienígenas).

\section{DA NECESSIDADE DE HOMOLOGAÇÃO}

Contrariamente ao entendimento acima exposto, a grande maioria dos doutrinadores pátrios defende que a promulgação, pelo Brasil, da Convenção de Nova lorque não ensejaria profundas alterações na disciplina da homologação de laudos arbitrais estrangeiros. Expõem, dentre outros e combatendo os argumentos da corrente contrária, os seguintes argumentos.

Revista Brasileira de Direito Internacional, Curitiba, v.2, n.2, jul./dez.2005 


\subsection{A EQUIPARAÇÃO DE EFEITOS ENTRE AS SENTENÇAS JUDICIAIS E ARBITRAIS}

Defendem os doutrinadores favoráveis a homologação de laudos arbitrais estrangeiros que, dentre as inovações trazidas pela Lei 9.307/1996, reside a equiparação entre a sentenças judiciais e arbitrais. Realmente estabelece seu art. 31 que "a sentença arbitral produz, entre as partes e seus sucessores, os mesmos efeitos da sentença proferida pelos órgãos do Poder Judiciário e, sendo condenatória, constitui título executivo".

$\mathrm{Na}$ lição de Carlos Alberto Carmona: "O legislador preferiu não utilizar na Lei de Arbitragem a expressão "laudo arbitral, substituindo-a por 'sentença arbitral', tudo a demonstrar que pretendeu atribuir à decisão dos árbitros eficácia de plena sentença"18

Logo, não só na nomenclatura "sentença" ficaram ambas equiparadas, mas também quanto aos efeitos produzidos. Destarte, nosso diploma processual, em seu art. 584, II, estabelece que a sentença arbitral constitui título executivo judicial. Sendo assim, o laudo arbitral interno prescinde de homologação pelo Judiciário, sendo executável de pleno direito. No mesmo sentido, os laudos arbitrais estrangeiros necessitarão, a exemplo das sentenças judiciais alienígenas, do exequatur do STJ para terem eficácia em território pátrio.

Ademais, cumpre enfatizar que essa necessidade de homologação de sentenças estrangeiras é de imperatividade constitucional. De fato, a Carta Magna, em seu art. 105, I, i, prevê ser de competência originária do STJ "a homologação das sentenças estrangeiras (...)". Ora, tendo em vista que a Constituição não diferencia entre sentença judicial e sentença arbitral, e porquanto seja a sentença arbitral equiparada à judicial, é constitucionalmente estabelecida a necessidade de homologação dos laudos arbitrais alienígenas. Aduz Pedro Baptista Matins: "com a sistemática implantada pela lei de

${ }^{18}$ CARMONA, Carlos Alberto. A arbitragem no Brasil no terceiro ano de vigência da Lei 9.307/1996. In: PUCCI, Adriana Noemi. Aspectos Atuais da Arbitragem, p. 45-46.

Revista Brasileira de Direito Internacional, Curitiba, v.2, n.2, jul./dez.2005 
arbitragem, tanto a homologação de sentença arbitral nacional, quanto aquela proferida no exterior independem da chancela estadual ordinária, exceto, nesta última hipótese, no que tange ao exequatur pelo STF, imposto constitucionalmente como medida imperativa para que produza efeitos no país"19. Outrossim, é essa a interpretação dada pelo art. 35 da Lei de Arbitragem, ex vi:

“Art. 35. Para ser reconhecida ou executada no Brasil, a sentença arbitral estrangeira está sujeita, unicamente, à homologação do Supremo Tribunal Federal".

Por fim, digno de transcrito um comentário ainda acerca da equiparação entre sentenças arbitrais e judiciais: "não se pode ir além e extrapolar os limites da equiparação estabelecida por lei, conferindo mais efeitos ao laudo arbitral que à sentença judicial. Caso seja realmente dispensado o procedimento homologatório dos laudos arbitrais estrangeiros e, por outro lado, seja mantida a necessidade de homologação das sentenças judiciais, advirá a esdrúxula situação em que as sentenças proferidas pelo Poder Judiciário de um Estado (...) teriam de passar pelo crivo do STF, enquanto os laudos arbitrais estrangeiros seriam conhecidos e executados, independentemente de homologação. Tal cenário poderia gerar até mesmo graves discussões e inegáveis problemas de ordem pública" ${ }^{20}$.

\subsection{DA SIMILITUDE ENTRE A CONVENÇÃO DE NOVA IORQUE E A} LEI 9.307/1996.

Como dito anteriormente, enfatizam inúmeros autores a similitude existente entre esse dois diplomas normativos da arbitragem. Enfocam, ademais, ser esse um dos motivos determinantes ao reconhecimento da continuação do juízo de delibação pelo STJ, uma vez que sua adesão não implicaria grandes modificações em nosso sistema homologatório.

Afirmam, outrossim, ser a Convenção de Nova lorque inspiradora de nossa legislação. Nesse sentido a lição de Beat Walter Rechsteiner: "A análise de todas as normas da Lei 9.307/1996, de 23.09.1996, referentes ao reconhecimento e à execução de sentenças arbitrais estrangeiras, revela,

\footnotetext{
${ }^{19}$ MARTINS. Pedro A. Baptista. A Arbitragem na visão do Poder Judiciário. Revista Doutrina n.․․ 11, p. 170.

${ }^{20}$ VERÇOSA, Fabiane. A (Des?)Necessidade de Homologação de Laudos Arbitrais Estrangeiros após a Entrada em Vigor, no Brasil, da Convenção de Nova lorque. Revista de Direito Mercantil, n.․13, p. 219.
}

Revista Brasileira de Direito Internacional, Curitiba, v.2, n.2, jul./dez.2005 
porém, revela uma influência muito forte da Convenção de Nova lorque, de 10.06.1958" 21 .

Aduzem que a simples comparação entre os arts. 38 e 39 da Lei de Arbitragem e 0 art. $V$ da Convenção - dispositivos que tratam do reconhecimento dos laudos arbitrais estrangeiros - demonstra tal alegação. Nesse diapasão leciona, dentre outros, Carlos Alberto Carmona e José Maria Rossani Garcez; sendo palavras deste último “..., a Lei de Arbitragem, em seus arts. 38 e 39, prevê, de forma quase idêntica à que se encontra prevista no art. V, 1 e 2 da referida Convenção, as hipóteses nas quais pode vir a ser negada, no Brasil, a homologação para o reconhecimento ou execução de sentença arbitral estrangeira. Com efeito as hipóteses previstas no art $V, 1$ e 2 da referida Convenção pouco ou nada diferem daquelas previstas nos arts. $38 \mathrm{e}$ 39 da Lei brasileira"22. Ex vi os aludidos artigos:

"Art. V.

1. O reconhecimento e a execução de uma sentença poderão ser indeferidos, a pedido da parte contra a qual ele é invocada, unicamente se esta parte fornecer à autoridade competente onde se tenciona o reconhecimento e a execução, prova de que:

a) as partes do acordo a que se refere o art. II estavam, em conformidade com a lei a elas aplicável, de algum modo incapacitadas, ou que tal acordo não é válido nos termos da lei à qual as partes o submeteram, ou, na ausência de indicação sobre a matéria, nos termos da lei do país onde a sentença foi proferida; ou

b) a parte contra a qual a sentença é invocada não recebeu notificação apropriada acerca da designação do árbitro ou do processo de arbitragem, ou lhe foi impossível, por outras razões, apresentar seus argumentos; ou

c) a sentença se refere a uma divergência que não está prevista ou que não se enquadra nos termos da cláusula de submissão à arbitragem, ou contém decisões acerca de matérias que transcendem o alcance da cláusula de submissão, contanto que, se as decisões sobre a matérias suscetíveis de arbitragem puderem ser separadas daquelas não suscetíveis, a parte da sentença que contém decisões sobre a matéria suscetíveis de arbitragem possa ser reconhecida ou executada; ou

d) a composição da autoridade arbitral ou o procedimento arbitral não se deu em conformidade com o acordado pelas partes, ou na ausência de tal acordo, não se deu em conformidade com a lei do país em que a arbitragem ocorreu; ou

e) a sentença ainda não se tornou obrigatória para as partes, ou foi anulada ou suspensa por autoridade competente do país em que, ou em conformidade com a lei do qual, a sentença tenha sido proferida.

\footnotetext{
${ }^{21}$ BEAT, Walter Rechsteiner. Arbitragem Privada Internacional: Teoria e Prática, $2^{\mathrm{a}}$ ed., p. 143.

22 GARCEZ, José Maria Rossani. Técnicas de Negociação, Resolução e Alternativa de Conflitos: ADRS, Mediação, Conciliação e Arbitragem, p.150.
} 
2. O reconhecimento e a execução de uma sentença arbitral também poderão ser recusados caso a autoridade competente do país em que se tenciona o reconhecimento e a execução contatar que:

a) segundo a lei daquele país, o objeto da divergência não é passível de solução mediante a arbitragem;

b) o reconhecimento ou a execução da sentença seria contrário à ordem pública daquele país.

Art. 38. Somente poderá ser negada a homologação para o reconhecimento ou execução de sentença arbitral estrangeira, quando o réu demonstrar que:

I - as partes na convenção de arbitragem eram incapazes;

II - a convenção de arbitragem não era válida segundo a lei à qual as partes a submeteram, ou, na falta de indicação, em virtude da lei do país onde a sentença arbitral foi proferida;

III - não foi notificado da designação do árbitro ou do procedimento de arbitragem, ou tenha sido violado o princípio do contraditório, impossibilitando a ampla defesa;

IV - a sentença arbitral foi proferida fora dos limites da convenção de arbitragem, e não foi possível separar a parte excedente daquela submetida à arbitragem;

V - a instituição da arbitragem não está de acordo com o compromisso arbitral ou cláusula compromissória;

VI - a sentença arbitral não se tenha, ainda, tornado obrigatória para as partes, tenha sido anulada, ou, ainda, tenha sido suspensa por órgão judicial do país onde a sentença arbitral for prolatada.

Art. 39. Também será denegada a homologação para o reconhecimento ou execução da sentença arbitral estrangeira, se o Supremo Tribunal Federal constatar que:

I - segundo a lei brasileira, o objeto do litígio não é suscetível de ser resolvido por arbitragem;

II - a decisão ofende a ordem pública nacional.

Parágrafo único. Não será considerada ofensa à ordem pública nacional a efetivação da citação da parte residente ou domiciliada no Brasil, nos moldes da convenção de arbitragem ou da lei processual do país onde se realizou a arbitragem, admitindo-se, inclusive, a citação postal com prova inequívoca de recebimento, desde que assegure à parte brasileira tempo hábil para o exercício do direito de defesa.".

Tais apontamentos vêm tão somente a corroborar a tese de que, com a promulgação da Convenção de Nova lorque, pouca (quiçá nenhuma) alteração seria infligida ao nosso sistema homologatório de sentenças arbitrais estrangeiras.

Um outro ponto, igualmente ressaltado, refere-se a não previsão pela Convenção de Nova lorque, de um procedimento homologatório; limita-se à apenas estabelecer as hipóteses em que o reconhecimento do laudo pode ser negado. Outorgou, o Tratado, aos Estados signatários a liberdade de disporem sobre o procedimento a ser adotado para o reconhecimento dos laudos alienígenas. Sendo assim, imperioso concluir-se que a Convenção não afasta, de plano, a necessidade de homologação do laudo arbitral estrangeiro. 


\subsection{O ARTIGO ३ DA CONVENÇÃO DE NOVA IORQUE}

Conforme salientado antanho, o âmago da discussão acerca de eventual dispensa de homologação, com a internalização da Convenção de Nova lorque, reside no art. III do aludido Acordo. No tópico antecedente já tratou-se da interpretação dada pela corrente simpática à dispensa de homologação. Agora, analisar-se-á o ponto de vista dos adeptos da necessidade de continuação da homologação.

Pois bem. Defende tal corrente que o enunciado do art. III da Convenção (vide supra), mais especificamente a expressão "condições substancialmente mais onerosas", estaria a se referir a encargos pecuniários. Alegam que a interpretação sistemática do disposto levaria a tal entendimento. Ora, o referido artigo menciona, em sua redação, "taxas ou cobranças mais altas do que as impostas para o reconhecimento ou execução de sentenças domésticas", remetendo, pois, à idéia de pecúnia, valor financeiro. Ademais, a própria expressão "onerosas" tem, dentre outras, por acepção a de ônus, custas.

Outrossim, recorrer-se à versão original do Tratado só legitima tal entendimento; uma vez os termos usados (a saber, "fees or charges") conduzem à noção de pecúnia, de numerário, verbis:

\footnotetext{
“Article III. Each Contracting State shall recognize arbitral awards as binding and enforce them in accordance with the rules of procedure of the territory where the awards is relied upon, under the conditions laid down in the following articles. There shall not be imposed substantially more onerous conditions or higher fees or charges on the recognition or enforcement of arbitral awards to which this Convention applies than are imposed on the recognition of enforcement of domestic arbitral awards"
}

De fato. O acompanhamento de qualquer processo demanda gastos financeiros, tem-se custas processuais, honorários advocatícios, etc. Ademais, por vezes, até mesmo a sobrecarga processual dos juízos, conseguindo numa 
maior morosidade, acaba por implicar em aumento de dispêndio pelo autor (ou pelas partes). Dessa forma, o objetivo do Tratado foi o de se vedar um recolhimento de custas tais que tornasse por demais dificultosa (senão impossível) a execução da sentença arbitral estrangeira.

\title{
3.4 POSIÇÃO DO STF/STJ
}

Por fim, analisar-se-á, a posição dominante na jurisprudência pátria. Contudo, tendo em vista ser recente a mudança de competência (do STF para o STJ), observar-se-á tanto a posição do STF quanto a do STJ.

Pois bem. nossas Supremas Cortes, em inúmeros julgados, acataram a possibilidade de se homologar laudos arbitrais alienígenas. Realmente, é o que se infere dos quatro julgados (dois do STF, e dois do STJ) a seguir transcritos:

\begin{abstract}
"SENTENÇA ARBITRAL ESTRANGEIRA. PEDIDO DE HOMOLOGAÇÃO. CONTRATO DE AFRETAMENTO. REQUISITOS PREVISTOS NO REGIMENTO INTERNO DO STF E NA LEI N ${ }^{\circ}$ 9.307/96 (LEI DA ARBITRAGEM). Tendo as normas de natureza processual da Lei

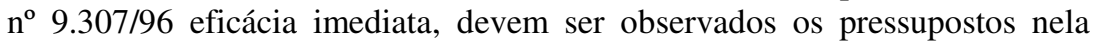
previstos para homologação de sentença arbitral estrangeira, independentemente da data de início do respectivo processo perante o juízo arbitral. Pedido que cumpre os requisitos dos arts. 37 a 39 da mencionada lei, bem como os dos arts. 216 e 217 do RI/STF. Homologação deferida",23
\end{abstract}

"HOMOLOGAÇÃO DE LAUDO ARBITRAL ESTRANGEIRO. REQUISITOS FORMAIS: COMPROVAÇÃO. CAUÇÃO: DESNECESSIDADE. INCIDÊNCIA IMEDIATA DA LEI No 9.307/96. CONTRATO DE ADESÃO: INEXISTÊNCIA DE CARACTERÍSTICAS PRÓPRIAS. INAPLICAÇÃO DO CÓDIGO DE DEFESA DO CONSUMIDOR. 1. Hipótese em que restaram comprovados os requisitos formais para a homologação (RISTF, artigo 217). 2. O Supremo Tribunal Federal entende desnecessária a caução em homologação de sentença estrangeira (SE no 3.407, Rel. Min. OSCAR CORRÊA, DJ DE 07.12.84). 3. As disposições processuais da Lei $n^{\circ}$ 9.307/96 têm incidência imediata nos casos pendentes de julgamento (RE $n^{\circ}$ 91.839/GO, RAFAEL MAYER, DJ de 15.05.81). 4. Não é contrato de adesão aquele em que as cláusulas são modificáveis por acordo das partes. 5. O Código de Proteção e Defesa do Consumidor, conforme dispõe seu artigo $2^{\circ}$, aplica-se somente a "pessoa física ou jurídica que adquire ou utiliza produto ou serviço como destinatário final". Pedido de homologação deferido,"24

${ }^{23}$ STF. SEC 5828 / NO - NORUEGA. SENTENÇA ESTRANGEIRA CONTESTADA. Rel. Min.ILMAR GALVÃO. TRIBUNAL PLENO. Julgamento em 06/12/2000. DJ 23/02/2001.

${ }^{24}$ STF. SEC 5847 / IN - GRA BRETANHA (INGLATERRA). SENTENÇA ESTRANGEIRA CONTESTADA. Rel. Min. MAURÍCIO CORRÊA. TRIBUNAL PLENO. Julgamento em 01/12/1999. DJ 17/12/1999.

Revista Brasileira de Direito Internacional, Curitiba, v.2, n.2, jul./dez.2005 
"HOMOLOGAÇÃO DE SENTENÇA ESTRANGEIRA. SENTENÇA ARBITRAL. PROCEDIMENTO

ARBITRAL QUE TEVE CURSO À REVELIA DO REQUERIDO. CONVENÇÃO ARBITRAL.

INEXISTÊNCIA.

1. Para a homologação de sentença de arbitragem estrangeira proferida à revelia do requerido, deve ele, por ser seu o ônus, comprovar, nos termos do inciso III do art. 38 da Lei n. 9.307/96, que não foi devidamente comunicado da instauração do procedimento arbitral.

2. Homologação deferida." 25

"SENTENÇA ESTRANGEIRA. HOMOLOGAÇÃO. INEXISTÊNCIA DE OFENSA Â ORDEM

PÚBLICA, À SOBERANIA NACIONAL E AOS BONS COSTUMES.

1. Sentença arbitral que decorreu de processo sem qualquer vício formal.

2. Contestação da requerida no sentido de que não está obrigada a cumprir o seu encargo financeiro porque a requerente não atendeu à determinada cláusula àcontratual. Discussão sobre a regra do exceptio non adimpleti contractus, de acordo com o art. 1.092 do Código Civil de 1916, que foi decidida no juízo arbitral. Questão que não tem natureza de ordem pública e que não se vincula ao conceito de soberania nacional.

3. Força constitutiva da sentença arbitral estrangeira por ter sido emitida formal e materialmente de acordo com os princípios do nosso ordenamento jurídico.

4. Homologação deferida ${ }^{26}$. Honorários advocatícios fixados em $10 \%$ (dez por cento) sobre o valor da causa."

Dessa forma, é de entendimento pacificado, tanto Supremo Tribunal Federal quanto no Superior Tribunal de Justiça, a viabilidade, senão a necessidade, de homologação de sentenças arbitrais estrangeiras. Ora, nos julgados acima colimados nada se discute acerca do exequatur ser apenas para sentenças judiciais estrangeiras. Do contrário, todas as decisões deferiram o pedido homologatório dos laudos arbitrais estrangeiros. Outrossim, saliente-se que sendo o STF o juízo último de interpretação constitucional, considerado inclusive o "Guardião da Constituição", seria essa a autoridade mais competente para dar uma interpretação final ao artigo art. 105, I, i,.

\section{UMA BREVE ANÁLISE DA LEGISLAÇÃO COMPARADA}

\footnotetext{
${ }^{25}$ STJ. SEC 887 / EX. SENTENÇA ESTRANGEIRA CONTESTADA. Rel. Min. JOÃO OTÁVIO DE NORONHA. CORTE ESPECIAL. Julgamento em 06/03/2006. DJ 03/04/2006.

${ }^{26}$ STJ. SEC 802 / EX. SENTENÇA ESTRANGEIRA CONTESTADA. Rel. Min. JOSE DELGADO. CORTE ESPECIAL. Julgamento em 18/08/2005. DJ 19/09/2005.
}

Revista Brasileira de Direito Internacional, Curitiba, v.2, n.2, jul./dez.2005 
Antes de adentrar-se nas conclusões finais, é de todo oportuno analisar, ainda que brevemente, legislações estrangeiras. Nesse sentido, e tendo em vista uma maior proximidade territorial, cultural, social, etc., tomou-se por base, para a elaboração dessa breve análise comparativa, países pertencentes ao cone sul. Importante, ademais, destacar que a paulatina evolução do instituto da arbitragem nesses países fora engendrada, dentre outros, pela intensificação do intercâmbio comercial entre os mesmos incremento esse fruto do Mercosul. Outrossim, com essa ampliação do mercado regional, diferenças existentes entre as legislações desses países, as diversas formas de interpretações da lei, e a formação profissional de operadores do direito, ficaram em evidência. Nesse diapasão, o instituto da arbitragem se apresenta como panacéia a resolução de eventuais conflitos entre os particulares que investem ou trabalhem nos países desses blocos econômicos.

Posto isto, não nos cabe, diante do objeto do presente artigo, analisar cabalmente as legislações, os procedimentos inerentes à arbitragem desses países. Limitar-se-á, nesse sucinto exame, a averiguar a existência ou não, em algum desses países, de um procedimento autônomo - distinto e independente da ação de execução - para o reconhecimento dos laudos arbitrais estrangeiros. Nesse sentido, focar-se-á o estudo em dois países, a saber, Uruguai e Argentina, ambos Estados-membros da Convenção de Nova lorque de 1958.

Pois bem. No Uruguai, por força do disposto nos arts. 541.2 e art. 543, o laudo arbitral estrangeiro precisa obter o exequatur perante a Suprema Corte de Justicia, ex vi:

\footnotetext{
“Artículo 541.

(...)

541.2 La ejecución se pedirá ante la Suprema Corte de Justicia.

(...)

Artículo 543

Laudos arbitrales extranjeros. Lo dispuesto em este Capítulo será apicable a los laudos dictados por tribunales Arbitrales extranjeros, em todo lo que fuere pertinente."
}

Revista Brasileira de Direito Internacional, Curitiba, v.2, n.2, jul./dez.2005 
Contudo, uma vez homologado, o laudo arbitral alienígena poderá ser executado perante o juízo competente para a execução - art. 541.3 do Código General Del Proceso, vide:

\author{
“Artículo 541. \\ (...) \\ 541.3 Si se hiciere lugar a la ejecución, se remitirá la sentencia al tribunal \\ competente para ello, a efectos de que proceda conforme com los trámites \\ que correspondan a la naturaleza de la sentencia".
}

$\mathrm{Na}$ Argentina, igualmente, os laudos arbitrais estrangeiros são executados seguindo o procedimento para a execução de sentenças judiciais estrangeiras. Contudo, diversamente do caso uruguaio, a execução dessas sentenças é requerida no juiz de primeira instância, o qual proferirá o exequatur (esse procedimento seguirá o trâmite dos incidentes processuais); decidindo-se pela homologação da execução, essa se procederá na forma estabelecida para as sentenças proferidas por tribunais argentinos. É o que se absorve do enunciado do art. 518, e 519 bis do Código Procesal Civil y Comercial de la Republica Argentina:

\footnotetext{
"Art. 518 - La ejecution de la sentencia dictada por UN (1) tribunal extranjero se pedirá ante el juez de primeira instancia que correponda, acompañada su testimonio y traducido y las actuaciones que acrediten que ha quedade ejecutoriada y que se han cumplido los demás requisitos, si no resultaren de la sentencia misma.

Para el trámite del exequátur se aplicarán las normas de los incidentes.

Si se dispusiere la ejecución, se procederá en la forma establecida para las sentencias pronunciadas por tribunales argentinos.

(...)

Art. 519 BIS - Los laudos pronunciados por tribunales arbitrales extranjeros podrán ser ejecutados por el procedimiento establecido en los articulos anteriores (...)".
}

Logo, dessa singela análise de legislação comparada, depreende-se que já é da práxis sul americana a exigência de homologação de laudos arbitrais estrangeiros, não obstante, serem todos esses países aderentes da Convenção de Nova lorque. Contudo, enquanto no Uruguai tal procedimento é realizado na Suprema Corte de Justiça, na Argentina o mesmo se desenrola no juízo de primeira instância mesmo. Assim, o fato de um Estado ter promulgado a Convenção não significa necessariamente a impossibilidade, de esse mesmo 
Estado, estabelecer um procedimento de homologação de laudos arbitrais alienígenas.

\section{CONSIDERAÇÕES FINAIS}

O fato de a jurisprudência pátria, como um todo, entender ser necessária a prévia homologação de sentenças arbitrais estrangeiras poderia suscitar a indagação de ser a polêmica, ainda hoje, presente. Contudo, mister é enfocar que a discussão reside na esfera doutrinária, e que, a jurisprudência, via de regra, espelha a opinião da maioria doutrinária. Mister ainda enfocar que, mesmo que um entendimento seja hoje pacificado, amanhã poderá não o ser, ou ainda ser pacificado o entendimento contrário. Quer isso dizer que, é por meio da discussão doutrinária, do cotejo argumentativo, que a ciência do direito progride; de modo que, não obstante, a polêmica não ser atualmente muito acessa, nada impede de amanhã não o será. Feito esse parênteses, passa-se às considerações finais.

Por todo o esboçado no presente trabalho, é claramente percebível que a questão da necessidade ou não de prévia homologação pelo STJ dos laudos arbitrais estrangeiros não se iniciou quando da promulgação da Convenção de Nova lorque. Muito pelo contrário, essa discussão já estava em curso quando esse Tratado começou a viger. Contudo, o que não pode deixar de ser notado é que a internalização desse Acordo reascendeu a discussão, trazendo elementos novos a mesma. Nesse sentido, tender para uma ou outra corrente é defender não a desnecessidade de homologação, porque o artigo III da Convenção de Nova lorque revogou o disposto na Lei de Arbitragem, ou a necessidade, haja vista a interpretação errônea desse dispositivo. Não. A questão de tomar partido (ainda que parcial) em uma ou outra direção é inerente a crenças mais intrínsecas, a opiniões sedimentadas, a adesão a teorias já desenvolvidas. Dessa forma, a conclusão se desenrolará pelo cotejo dos argumentos, não se atendo, assim, apenas ao artigo III da Convenção, ou ao disposto na mesma.

Revista Brasileira de Direito Internacional, Curitiba, v.2, n.2, jul./dez.2005 
Posto isso, primeiramente mister é salientarmos que a ciência jurídica, enquanto ciência, tem de primar, dentre outras coisas, pelo rigor conceitual, metodológico, lingüístico, etc. Nesse sentido, dizer-se que o termo sentença abrangeria tanto a judicial quanto a arbitral, é não resguardar tal rigorismo. Ora, o CPC, em seu art. 162, § 1, estabelece que sentença é "é o ato pelo qual o juiz põe termo ao processo, decidindo ou não o mérito da causa". Logo, a Lei de Arbitragem ao se referir ao laudo arbitral como sentença arbitral, acabou por mesclar, misturar dois institutos díspares: laudo arbitral e sentença judicial. Poder-se-ia, ademais, argüir que o termo só fora empregado na Lei Marcos Maciel para enfocar a proximidade entre um e outro instituto. Porém, tal resultado poderia ser atingido fazendo-se uma ressalva no corpo da lei de que os laudos arbitrais possuem os mesmo efeitos inerentes às sentenças judiciais. Portanto, como uma primeira crítica, vislumbra-se a necessidade, para um maior rigor científico, de uma revisão terminológica da expressão "sentença arbitral": o termo sentenças só será tecnicamente bem empregado se referir-se ao ato judicial que põe fim ao processo.

Outra conseqüência nefasta do emprego indiscriminado desse termo, é a considerada equiparação entre a sentença judicial e a arbitral, defendida pelos defensores da homologação. Afirma, essa corrente, que para além de uma equivalência textual, haveria a dos efeitos de ambas as "sentenças". Alega, outrossim, que o diploma processual, ao prever que o laudo arbitral constitui título executivo judicial só reforçaria tal equiparação. Contudo, data a máxima vênia, é clarividente que sentença judicial e laudo arbitral são institutos distintos. Realmente, enquanto a sentença judicial corporifica autoridade estatal, é fruto, em poucas palavras, do exercício da soberania (autoridade) estatal, o laudo arbitral estrangeiro é resultado de uma convenção particular, de um compromisso firmado por particulares para solução de pendengas de caráter patrimonial. Pois, se assim é, não se justifica equiparar a sentença judicial ao laudo arbitral: o que se poderia afirmar é a proximidade desses institutos, mais especificamente, a imputação aos laudos arbitrais de alguns dos efeitos que são inerentes às sentenças judiciais (visando ao incentivo da prática da arbitragem).

Revista Brasileira de Direito Internacional, Curitiba, v.2, n.2, jul./dez.2005 
Tal distinção há de estar presente quando se interpreta as leis tratantes da arbitragem. Nesse espectro, a Constituição quando outorga ao STJ a competência para homologar sentenças estrangeiras, está a referir-se a sentenças judiciais estrangeiras. A uma porque quando da elaboração da Constituição Federal (final da década de 80 ), não se falava em "sentenças arbitrais", porquanto esse termo só fora posteriormente empregado pela Lei $9.307 / 96^{27}$. A duas porque, como já fora exaustivamente assinalado anteriormente, os dois institutos (sentença judicial e laudo arbitral) têm natureza distintas.

É certo, outrossim, que a prática brasileira perpetuou a utilização do exequatur igualmente para os laudos arbitrais estrangeiros, mesmo após o advento da Lei de Arbitragens, e da Convenção de Nova lorque. Frise-se, porém, que tal prática acabou por tornar-se tradição, sem que eventuais questionamentos posteriores, acerca do cabimento de sua continuação ou não, fossem realizados. De fato, anteriormente à elaboração de nossa Lei de Arbitragem, os tribunais formaram jurisprudência, a despeito da falta de previsão legal, no sentido de uma dupla homologação dos laudos arbitrais estrangeiros - prática essa não incentivadora da utilização desse instituto. Pois bem, com o advento da Lei de Arbitragem, regulamentando todo esse proceder estatal, dispensou-se essa dupla homologação, estabelecendo-se porém a necessidade do juízo de delibação (a exemplo das sentenças judiciais). Contudo, os laudos arbitrais nacionais, que anteriormente também prescindiam de um juízo homologatório para serem executáveis, passaram a ser títulos executivos judiciais. Ora, simplesmente acatou-se tais disposições (o laudo arbitral estrangeiro porque mais de acordo à tradição de homologação firmada), sem que se discutisse seriamente a licitude de dispensar-se tratamento tão distinto a laudos arbitrais nacionais e estrangeiros.

Observe-se, além disso, que o acatamento desses dispositivos leva ao cúmulo de ser possível a execução direta de laudos arbitrais proferidos no Brasil, mesmo que tenha por base legislação de outro país; ao passo que laudos proferidos em outros Estados, mas segundo leis brasileiras

\footnotetext{
${ }^{27}$ É certo que poder-se-ia alegar recepção por parte da Constituição do disposto nessa Lei de Arbitragem; contudo, é preciso que se tenha sempre em conta a dicotomia dos institutos.
}

Revista Brasileira de Direito Internacional, Curitiba, v.2, n.2, jul./dez.2005 
necessitariam do exequatur do STJ. Ademais, imperioso ressaltar-se que títulos executivos estrangeiros são diretamente executáveis no juízo competente, não Ihes sendo necessário qualquer juízo homologatório. Veja -se o seguinte julgado:

"RECLAMAÇÃO - TÍTULOS DE CRÉDITOS CONSTITUÍDOS NO
EXTERIOR - PRETENDIDA HOMOLOGAÇÃO, PELO SUPREMO
TRIBUNAL FEDERAL, COM O OBJETIVO DE OUTORGAR-LHES
EFICÁCIA EXECUTIVA - INADMISSIBILIDADE -
INAPLICABILIDADE DO ART. 102, I, 'H' DA CONSTITUIÇÃO -
CONSEQUENTE INOCORRÊNCIA DE USURPAÇÃO DA
COMPETENCIA DO SUPREMO TRIBUNAL FEDEAL -
DESCABIMENTO DA RECLAMAÇÃO - RECURSO DE AGRAVO
IMPROVIDO - Os títulos de crédito constituídos em país estrangeiro, para
serem executados no Brasil (CPC, art. 585, § 2'), não dependem de
homologação pelo Superior Tribunal Federal. A eficácia executiva que lhe é
inerente não se subordina ao juízo de delibação a que se refere o art. 102, I
'h', da Constituição, que incide unicamente sobre 'sentenças estrangeiras',
cuja noção conceitual não compreende, não abrange e não se estende aos
títulos de crédito, ainda que sacados ou constituídos no exterior. Doutrina.
Precedentes. - Não estando em causa a possibilidade de usurpação da
competência do Supremo Tribunal Federal, torna-se inviável a utilização da
reclamação, quando promovida contra decisão de Tribunal judiciário, que,
por entender incabível a exigência da prévia homologação a que se refere o
art. 102, I, 'h', da Carta Política, declara revestir-se de plena eficácia
executiva, em território nacional, título de crédito constituído em país
estrangeiro,"28

Pois bem. Se um título de crédito estrangeiro, que é, em última análise um título executivo, pode ser diretamente apresentado no juízo de primeiro grau, porque o laudo arbitral haveria de ser diferente? Dessa maneira, e de acordo com o exposto acima, caberia mais razão à corrente minoritária que defende a desnecessidade de homologação pelo STJ. Contudo, há igualmente elementos preciosos defendidos pela corrente favorável à continuação da homologação por esse Tribunal de Justiça, os quais não podem deixar de serem cultivados.

Nesse sentido, afirma-se que o exequatur é questão de defesa de soberania. Contudo, tal afirmação deveria ser posta de uma outra maneira, visando a um maior rigor técnico. Realmente o juízo de delibação visa a controlar, ainda que formalmente, as sentenças, as decisões proferidas fora do território nacional, que, por um motivo ou outro, haverão de ser executadas por

${ }^{28}$ STF. RECL 1908 / SP. AGRAVO REGIMENTAL NA RECLAMAÇÃO. Rel. Min.CELSO
MELLO. TRIBUNAL PLENO. Julgamento em 24/10/2001. DJ 03/12/2004.

Revista Brasileira de Direito Internacional, Curitiba, v.2, n.2, jul./dez.2005 
nosso Judiciário. Todavia, daí a se afirmar tratar-se de defesa, de uma questão de soberania há uma grande diferença. Só se estará a falar em soberania quando a decisão, objeto da execução, advier de órgão estatal, revestido portanto de autoridade pública; e não quando a decisão provier de juízo arbitral, decorrente de acordo, compromisso entre particulares. Assim, o que deve ficar patente é a necessidade sim de se controlar as decisões alienígenas que serão aqui executadas. Entretanto, imputar tal controle ao STJ, a semelhança das sentenças judiciais, sob o auspício, errôneo, de se defender a soberania nacional, é no mínimo exagerado. Nesse diapasão, a solução argentina nos seria de muita valia: á semelhança do laudo arbitral nacional, o estrangeiro, poderia ser apresentável diretamente ao juízo competente para a execução, o qual estaria, ademais, incumbido de promover um juízo homologatório prévio, que analisasse a não incidência de quaisquer das condições impeditivas, ou atentatórias a moral e a ordem pública.

Em apertada síntese, o que parece ser o mais correto é cotejar-se ambas as propostas afim de se resgatar um maior rigor técnico, e institucional, com a desnecessidade do juízo de delibação, para os laudos arbitrais estrangeiros, pelo STJ; ao passo em que se defende a continuação de um controle judicial (pelo juízo competente para a execução) das decisões passíveis de execução no Brasil.

\section{REFERÊNCIAS}

AMARAL, Antônio Carlos Rodrigues do (coord.). Direito do Comércio Internacional: Aspectos Fundamentais. São Paulo: Ed. Aduaneiras, 2004.

ARAÚJO, Nádia de. Contratos Internacionais. Autonomia da Vontade, Mercosul e Convenções Internacionais, $3^{\text {a }}$ ed rev. e ampliada, de acordo com o novo CC e a Convenção de Nova York. Rio de Janeiro: Ed. Renovar, 2004;

CARMONA, Carlos Alberto. A Arbitragem no Brasil no terceiro ano de vigência da Lei 9.307/1996. In: PUCCI, Adriana Noemi, Aspectos Atuais da Arbitragem. Rio de Janeiro: Forense, 2001;

CREMADES, Bernardo M. Latin American Courts and International Arbitration. Revista de Arbitragem e Mediação, número 3, p.20-46; 
FÉRES, Marcelo Andrade. Repensando as condições de reconhecimento e execução de sentenças arbitrais estrangeiras no Brasil. Jus Navegandi, Teresina, a. 5, n. 50, abr.2001. Disponível em:

http://jus2.uol.com.br/doutrina/texto.asp?id=1989 (acessado em 10/07/2005);

GARCEZ, José Maria Rossani. Técnicas de Negociação, Resolução Alternativa de Conflitos: ADRS, Mediação, Conciliação e Arbitragem. Rio de Janeiro: Lúmen Júris, 2002;

GLITZ. Frederico Eduardo Zenedin. A Arbitragem internacional como sistema de solução privada de controvérsias. Jus Navegandi, Teresina, a. 6, n. 59, out.2002. Disponível em: http://www1.jus.com.br/doutrina/imprimir.asp?id=3260 (acessado em 26/03/2005);

GOYOS JR., Durval de Noronha. A Arbitragem na Área de Livre Comércio da Américas (ALCA). Revista de Arbitragem e Mediação, número 1, p.32-39;

MAGALHÃES, José Carlos de. Reconhecimento e Execução de laudos arbitrais estrangeiros. Revista dos Tribunais, São Paulo, v. 740, p.116-127, jun./97;

PUCCI, Adriana Noemi. A Arbitragem nos Países do Mercosul. Revista dos Tribunais, São Paulo, v. 738, p.41-69, abril/99;

RECHSTEINER, Beat Walter. Arbitragem Privada Internacional: Teoria e Prática, 2ª ed. São Paulo: Ed. RT, 2001;

VALENÇA FILHO. Clávio de Melo. Ratificação da Convenção sobre o Reconhecimento e a Execução de Sentenças Arbitrais Estrangeiras (Nova Iorque, 1958). Revista de Direito Bancário, do Mercado de Capitais e da Arbitragem, , n. 16, p. 387-390, jun./2002;

VALLADÃO, Haroldo. "Parecer", Revista Forense, São Paulo, n. 138, p. 401409, nov./51;

VANNUCHI, Camilo. A Sociedade do Excesso. Revista Isto É. Ed. Abril, edição 1819, 18/08/2004. Disponível em:

http://www.terra.com.br/istoe/1819/comportamento/1819 sociedade do excess o.htm (acessado em 10/09/2005);

Revista Brasileira de Direito Internacional, Curitiba, v.2, n.2, jul./dez.2005 